\title{
Weed Based Organic Fertilizer to Reduce Application of Synthetic Fertilizer in Mustard (Brasiccasinensis L.)
}

\section{N. Setyowati ${ }^{*}$ Z. Muktamar and I. Puspitasari}

\author{
Agronomy Departement, University of Bengkulu, Bengkulu, Indonesia
}

N. Setyowati, Z. Muktamar and I. Puspitasari (2015). Weed Based Organic Fertilizer to Reduce Application of Synthetic Fertilizer in Mustard (Brassica sinensis L.). Journal of Agricultural Technology 11(8):1677-1683.

Conventional agriculture has put the use of synthetic fertilizer as an important agrochemical input to increase plant productivity since such fertilizer provides fast release of plant nutrients. However, for a long period of time, continuous application of such agrochemical depletes soil fertility. On the other hand, organic fertilizer such as weed based compost has benefit to improve soil properties eventhough nutrient release from such organic fertilizer is slower than that of synthetic fertilizer. Combination of both fertilizers will provide advantages to soil and plant. The objective of the experiment was to compare the growth and yield of mustard as influenced by wedelia compost and its combination with $\mathrm{N}, \mathrm{P}, \mathrm{K}$ fertilizer. The greenhouse experiment was carried out using completely randomized design. Treatments consisted of 100 $\mathrm{kg} \mathrm{N}, \mathrm{P}, \mathrm{K}$ fertilizer ha ${ }^{-1} ; 15$ ton wedelia compost ha ${ }^{-1}$ combined with $0,25,50$ and $75 \mathrm{~kg} \mathrm{~N}, \mathrm{P}$, $\mathrm{K}$ fertilizer ha ${ }^{-1}$ respectively; 20 ton wedelia compost ha ${ }^{-1}$ combined with $0,25.50$ and $75 \mathrm{~kg} \mathrm{~N}$, $\mathrm{P}, \mathrm{K}$ fertilizer $\mathrm{ha}^{-1}$ respectively. Treatment was replicated 4 times. The experiment indicated that wedelia compost and its combination with $\mathrm{N}, \mathrm{P}, \mathrm{K}$ fertilizer had no significant effect on most variable observed in this experiment. Application of wedelia compost at rate of 15 and 20 ton $\mathrm{ha}^{-1}$ and its combination with $\mathrm{N}, \mathrm{P}, \mathrm{K}$ fertilizer significantly increase mustard yield (shoot fresh weight) as compared to that of $100 \mathrm{~kg} \mathrm{~N}, \mathrm{P}, \mathrm{K}$ fertilizer ha ${ }^{-1}$. This result indicated that application of wedelia compost could substitute N, P, K fertilizer for growth and yield of mustard.

Keywords: Wedelia trilobata, wedelia, mustard, compost

\section{Introduction}

In last few decades, use of synthetic fertilizer has become common practices to improve agricultural productivity. Such fertilizer will release nutrients so rapidly that they are available for plant growth and development. However, for a long period of time, excessive application of such fertilizer depletes soil fertility. Previous study by Barack et al. (1997) indicated that long term application of nitrogen fertilizer caused significant increase in exchangeable Al, accompanied with reduction of Cation Exchange Capacity

\footnotetext{
*Coressponding Author: N. Setyowati, E-mail:nanik_srg@yahoo.com
} 
(CEC), base saturation, and exchangeable calcium (Ca) and magnesium ( $\mathrm{Mg}$ ). Other finding by Fang et al. (2012) pointed out that soil $\mathrm{pH}$ reduced significantly due to long term addition of nitrogen fertilizer.

Organic fertilizer is believed to increase fertility of degraded soil. Mineralization of soil organic matter slowly release plant nutrients (Foth and Ellis, 1997; Simanungkalit, 2006) and improve other physical, chemical, biological properties of soil. Other study by Kowaljowet al. (2010) showed that organic fertilizer significantly enhanced soil organic carbon, total nitrogen, extractable phosphorus, and potential nitrogen mineralization. Decomposition of organic matter also releases humic and fulvic acids, leading to increase soil $\mathrm{CEC}$ and providing significant role for organic mineral interaction in $\mathrm{C}$ stabilization within micro aggregates (Spark, 2003). Improvement of plant growth and yield as affected by organic fertilizer has been observed in chili pepper and pakchoi (Brassica oleracea L.)(Setyowatiet al., 2007; Setyowatiet al. 2014a). Organic matter can be derived from compost of various sources including weed biomass.

Selected weeds such as hyachinth (Eichorniacrassipes), wedelia (Wedeliatrilobata), siam weed (Cromolaenaordota) tithonia (Tithoniadiversifolia), and Agerathumconyzoides are prospective as sources of organic fertilizer (Maftu'ahet al., 2005; Supriyonoet al., 2005; Setyowatiet al. 2008; Iqua and Huasi, 2009; Setyowatiet al., 2014b). Previous study revealed that content of organic carbon, calcium, magnesium, potassium and total nitrogen of soil fertilized with wedelia compost was higher than that of cattle manure (Suntoroet al., 2001).

Combination of organic and synthetic fertilizers is necessary to fasten availability of nutrients to plant as well as to improve soil properties supporting the growth of plant. Previous research by Ullahet al. (2008) reported that combination of $60 \%$ organic and $40 \%$ synthetic fertilizers provided the best performance of eggplant as indicated by highest number of fruit per plant, fruit length, and fruit diameter. Similar study conducted by Ouda and Mahadeen (2008) showed that optimum yield of broccoli was gained by application of 60 $\mathrm{Mg}$ of manure and $60 \mathrm{~kg}$ synthetic fertilizer per ha. The study aimed to compare the growth and yield of mustard as affected by wedelia compost and its combination with $\mathrm{N}, \mathrm{P}, \mathrm{K}$ fertilizer.

\section{Materials and methods}

\section{Experimental Design and Treatment.}

The study was conducted from March to July 2014 at the Faculty of 
Agriculture, University of Bengkulu, Indonesia. The greenhouse experiment was carried out using Completely Randomized Design with 9 treatments as follows:

\begin{tabular}{ccc}
\hline & Treatment & \\
\hline & $\begin{array}{c}\text { NPK Fertilizer } \\
\left(\mathrm{kg} \mathrm{ha}^{-1}\right)\end{array}$ & $\begin{array}{c}\mathrm{WC} \\
\left(\mathrm{Mg} \mathrm{ha}^{-1}\right)\end{array}$ \\
\hline Control & $100^{*}$ & - \\
T-1 & 75 & 15 \\
T-2 & 75 & 20 \\
T-3 & 50 & 15 \\
T-4 & 50 & 20 \\
T-5 & 25 & 15 \\
T-6 & 25 & 20 \\
T-7 & - & 15 \\
T-8 & - & 20 \\
\hline
\end{tabular}

$\mathrm{WC}=$ Wedelia compost

Control was rate of NPK fertilizer based on recommendation for mustard cultivation. Each treatment was replicated 4 times.

\section{Composting Procedure.}

Wedelia compost was prepared by cutting into approximately $5 \mathrm{~cm}$ size of $75 \mathrm{~kg}$ wedelia leaves. The biomass was placed into wooden box and sprayed with EM-4 solution using small sprayer. The box was, then, covered with transparent plastic. The mixture was kept moist for 6 weeks and reversed every 2 days to maintain necessary oxygen. Matured compost was indicated by dark color. The compost was air-dried and sieved with $0.5 \mathrm{~mm}$ mesh screen before its application.

\section{Media Preparation.}

Soil used in this experiment was Ultisol from KandangLimun Village, Bengkulu, Indonesia, at altitude of approximately $15 \mathrm{~m}$ above sea level, located at altitude of about $102^{\circ} 16^{\prime} 59.8548^{\prime \prime} \mathrm{E}$ and $3^{\circ} 45^{\prime} 10.3824^{\prime \prime} \mathrm{S}$. Composite soil sample was collected from top soil (0-20 cm depth). The sample was air-dried for 48 hours, sieved through $2 \mathrm{~mm}$ mesh screen. A week before planting, $5 \mathrm{~kg}$ of soil was mixed with wedelia compost according to each treatment into $10-\mathrm{kg}$ polybag. Polybags were put in $45-\mathrm{cm}$ tall wooden rack. Soil was wetted to nearly water holding capacity. 


\section{Greenhouse Operation.}

Mustard seed was germinated in square seedling tray consisted of soil and compost mixture at 1:1 weight ratio. After 10 days, uniform seedlings were transplanted into previously prepared $10-\mathrm{kg}$ polybag. Each polybag contained 2 mustard seedlings and was thinned to one plant a week after transplanting. Nitrogen, $\mathrm{P}$ and $\mathrm{K}$ fertilizer for each treatment was applied a week after planting by mixing the fertilizer into approximately $2 \mathrm{~cm}$ depth from the soil surface. During the experiment, soil was kept moist by watering when required. Forty five days after transplanting, mustard was harvested by cutting polybag. Mustard shoot and root was separated from soil by gently watering the soil. The shoot and root were dried at $60-70{ }^{\circ} \mathrm{C}$ for 48 hours and weighed for dry weight. Observed variables included plant height, number of leaves, leaf area, leaf greenness, shoot fresh weight, root fresh weight, shoot dry weight, and root dry weight.

\section{Statistical Analysis.}

Statistical analysis was carried out using PROC GLM in Statistical Analysis System version 9.1.3 portable at $\mathrm{P}<0.05$. When there were significant differences, treatment means were separated using Duncan's Multiple Range Test.

\section{Result and Discussion}

Application of wedelia compost and its combination with NPK fertilizer had no significant influence on most variables observed in this experiment. Significant effect of fertilizer was detected only to fresh weight of mustard. Study by Setyowatiet al. (2009) pointed out similar result where wedelia organic fertilizer did not significantly affect on shoot dry weight, root dry weight, fruit length, and fresh weight of chili pepper. Olaniyi and Ojetayo (2011) also found that organic fertilizer did not give significant effect on plant height, number of leaves and shoot dry weight of cabbage. 
Table 1. Plant height, number of leaves, leaf greenness, and leaf area as influenced by wedelia compost and its combination.

\begin{tabular}{cccccc}
\hline \multicolumn{2}{c}{ Treatment } & \multicolumn{4}{c}{ Variables } \\
\hline $\begin{array}{c}\text { NPK Fertilizer } \\
\left(\mathrm{kg} \mathrm{ha}^{-1}\right)\end{array}$ & $\begin{array}{c}\mathrm{WC} \\
\left(\mathrm{Mg} \mathrm{ha}^{-1}\right)\end{array}$ & PH $(\mathrm{cm})$ & LN & LG & LA $\left(\mathrm{cm}^{2}\right)$ \\
\hline $100^{*}$ & - & $38.00 \mathrm{a}$ & $9.75 \mathrm{a}$ & $39.80 \mathrm{a}$ & $1814.75 \mathrm{a}$ \\
75 & 15 & $37.00 \mathrm{a}$ & $8.50 \mathrm{a}$ & $45.70 \mathrm{a}$ & $2219.00 \mathrm{a}$ \\
75 & 20 & $36.00 \mathrm{a}$ & $11.25 \mathrm{a}$ & $39.10 \mathrm{a}$ & $2379.50 \mathrm{a}$ \\
50 & 15 & $37.00 \mathrm{a}$ & $8.75 \mathrm{a}$ & $44.17 \mathrm{a}$ & $2348.75 \mathrm{a}$ \\
50 & 20 & $38.00 \mathrm{a}$ & $9.75 \mathrm{a}$ & $43.65 \mathrm{a}$ & $1491.00 \mathrm{a}$ \\
25 & 15 & $41.75 \mathrm{a}$ & $9.75 \mathrm{a}$ & $40.50 \mathrm{a}$ & $2276.50 \mathrm{a}$ \\
25 & 20 & $38.00 \mathrm{a}$ & $9.75 \mathrm{a}$ & $43.62 \mathrm{a}$ & $2145.75 \mathrm{a}$ \\
- & 15 & $39.00 \mathrm{a}$ & $10.25 \mathrm{a}$ & $46.72 \mathrm{a}$ & $1919.25 \mathrm{a}$ \\
- & 20 & $43.00 \mathrm{a}$ & $9.50 \mathrm{a}$ & $47.50 \mathrm{a}$ & $2003.75 \mathrm{a}$ \\
\hline
\end{tabular}

*) Control, $\mathrm{WC}=$ Wedelia compost, $\mathrm{PH}=$ plant height, $\mathrm{LN}=$ Leaf number, $\mathrm{LG}=$ Leaf greenness, LA = Leaf area. Treatment means within column followed by the same letter are not significantly differences at DMRT 5\%.

It was detected from Table 1 that application of $20 \mathrm{Mg}$ wedelia $\mathrm{ha}^{-1}$ tended to have tallest cabbage as compared to other treatments, while its combination with $75 \mathrm{~kg}$ NPK fertilizer provided shortest cabbage. However, it was not followed by the same trend on leaf area where combination of $20 \mathrm{Mg}$ wedelia ha ${ }^{-1}$ with $75 \mathrm{~kg}$ NPK fertilizer exhibited highest leaf area. This might be associated with higher number of leaves.

Unlike other variables, shoot fresh weight was significantly affected by wedelia compost and its combination with NPK fertilizer as seen in Table 2. Application of wedelia compost at rate of 15 and 20 ton $^{-1}$ and its combination with $\mathrm{N}, \mathrm{P}, \mathrm{K}$ fertilizer significantly increased mustard yield (shoot fresh weight) as compared to that of $100 \mathrm{~kg} \mathrm{~N}, \mathrm{P}, \mathrm{K}$ fertilizer ha ${ }^{-1}$. Treatment of $15 \mathrm{Mg}$ wedelia compost $\mathrm{ha}^{-1}$ increased yield by $93.1 \%$ as compared to $\mathrm{N}, \mathrm{P}, \mathrm{K}$ fertilizer alone. This indicated that wedelia compost had capability to substitute synthetic fertilizer.

Better yield performance of mustard grown in soil fertilized with wedelia compost might be related to sufficient availability of nutrients and improvement of other soil properties. Wedelia compost tested in this experiment contained $2.05 \% \mathrm{~N}, 1.59 \% \mathrm{P}$, and $3.59 \% \mathrm{~K}$. Upon decomposition, the compost released nutrient and was available to plant. Study by Meleroet al. (2008) confirmed that organic fertilized soil showed increase in total organic carbon, total nitrogen, available phosphorus, and exchangeable potassium.Application of wedelia compost at rate of $20 \mathrm{Mg} \mathrm{ha}^{-1}$ had no significant differences on mustard yield as compared to that of $15 \mathrm{Mg} \mathrm{ha}^{-1}$, indicating that rate of $15 \mathrm{Mg} \mathrm{ha}^{-1}$ gave sufficient nutrient for mustard growth. 
Table 2. Shoot fresh weight, shoot dry weight, root dry weight, total dry weight as influenced by wedelia compost and its combination.

\begin{tabular}{cccccc}
\hline \multicolumn{2}{c}{ Treatment } & \multicolumn{4}{c}{ Variables } \\
\hline $\begin{array}{c}\text { NPK Fertilizer } \\
\left(\mathrm{kg} \mathrm{ha}^{-1}\right)\end{array}$ & $\begin{array}{c}\text { WC } \\
\left(\mathrm{Mg} \mathrm{ha}^{-1}\right)\end{array}$ & $\begin{array}{c}\text { SFW } \\
\left(\mathrm{g} \mathrm{plant}^{-1}\right)\end{array}$ & $\begin{array}{c}\text { SDW } \\
\left(\mathrm{g} \mathrm{plant}^{-1}\right)\end{array}$ & $\begin{array}{c}\text { RDW } \\
\left(\mathrm{g} \mathrm{plant}^{-1}\right)\end{array}$ & $\begin{array}{c}\text { TDW } \\
\left(\mathrm{g} \mathrm{plant}^{-1}\right)\end{array}$ \\
\hline $\begin{array}{c}100^{*} \\
75\end{array}$ & - & $85.87 \mathrm{c}$ & $5.30 \mathrm{a}$ & $0.55 \mathrm{a}$ & $5.85 \mathrm{a}$ \\
75 & 15 & $121.27 \mathrm{bc}$ & $6.25 \mathrm{a}$ & $0.50 \mathrm{a}$ & $6.75 \mathrm{a}$ \\
50 & 20 & $141.45 \mathrm{ab}$ & $7.57 \mathrm{a}$ & $0.62 \mathrm{a}$ & $8.45 \mathrm{a}$ \\
50 & 15 & $139.17 \mathrm{ab}$ & $7.70 \mathrm{a}$ & $0.42 \mathrm{a}$ & $8.12 \mathrm{a}$ \\
25 & 20 & $148.40 \mathrm{ab}$ & $6.05 \mathrm{a}$ & $0.62 \mathrm{a}$ & $6.67 \mathrm{a}$ \\
25 & 15 & $154.60 \mathrm{ab}$ & $8.12 \mathrm{a}$ & $0.79 \mathrm{a}$ & $8.82 \mathrm{a}$ \\
- & 20 & $130.65 \mathrm{ab}$ & $8.42 \mathrm{a}$ & $0.42 \mathrm{a}$ & $8.85 \mathrm{a}$ \\
- & 15 & $165.82 \mathrm{a}$ & $7.67 \mathrm{a}$ & $0.67 \mathrm{a}$ & $8.32 \mathrm{a}$ \\
\hline
\end{tabular}

*) Control, WC = Wedelia compost, SFW = Shoot fresh weight, SDW = Shoot dry weight, RDW $=$ Root dry weight, TDW = Total dry weight. Treatment means within column followed by the same letter are not significantly differences at DMRT 5\%.

In summary, Application of wedelia compost at rate of 15 and 20 ton ha ${ }^{1}$ and its combination with $\mathrm{N}, \mathrm{P}, \mathrm{K}$ fertilizer significantly increased mustard yield (shoot fresh weight) as compared to that of $100 \mathrm{~kg} \mathrm{~N}, \mathrm{P}, \mathrm{K}$ fertilizer ha ${ }^{-1}$. Application of wedelia compost at rate of $15 \mathrm{~g} \mathrm{ha}^{-1}$ providednon significant yield performance when compared to that of $20 \mathrm{Mg} \mathrm{ha}^{-1}$. This result indicated that application of wedelia compost could substitute N, P, K fertilizer for mustard growth and yield

\section{References}

Barack, P., Jobe, B.O., Krueger, A.R., Peterson, L.A. and Laird, D.A.(1997). Effects of longterm soil acidification due to nitrogen fertilizer inputs in Wisconsin. Plant and Soil 197(1): 61-69.

Fang, Y., Xun, F., Bai, W., Zhang, and Li, L.(2012). Long term nitrogen addition leads to loss of species richness due to litter accumulation and soil acidification in a temperate steppe. Plos One 7(10): 1-8. www.plosone.org

Foth, H.D. and Ellis, B.G.(1997). Soil Fertility, $2^{\text {nd }}$ Ed. Lewis Publishers. New York.

Iqua, P. andHuasi, L.(2009). Effect of chicken manure, Tithoniadiversifolia and Albizziaspp on maize plant height and dry matter production - Lessons Learnt in the Eastern Highlands of PNG. p. 240-250. Proc. 17th International Farm Management Congress, Bloomington/Normal, Illinois, USA. July 2009.

Kowaljow, E., Mazzarino, M.J.,Satti, P. and Jimenez-Rodriguez, C.(2010). Organic and inorganic fertilizer effects on a degraded Patagonian rangeland. Plant Soil 332:135145.

Maftu'ah, E., Asikin, S. and Najib, A. (2005). Potensigulma CromolaenaodoratadanAgerathumconyzoidessebagaisumberpupuk $\quad \mathrm{N} \quad$ dan $\quad \mathrm{P}$ 
untukmenujusistempertanianorganik. Proc. KonferensiNasional XVII HimpunanIlmuGulma Indonesia.Yogyakarta 20-21 Juli 2005. (in Indonesian Language).

Melero, S., Madejón,E.1,Engracia, H., Francisco, J. and Ruiz, J.C.(2008). Effect of implementing organic farming on chemical and biochemical properties of an irrigated loam soil. Agron. J. 100(1):136-144.

Olaniyi, J.O. and Ojetayo, A.E.(2011). Effect of fertilizer types on the growth and yield of two cabbage varieties. J. Animal and Plant Sci. 12(2): 1573-1582

Ouda, B.A. and Mahadeen,A.Y. 2008.Effect of fertilizers on growth, yield, yield components, quality and certain nutrient contents in broccoli (Brassica oleracea). Int. J. Agri. Biol., 10: 627-32.

Setyowati, N., Nurjanah, U. and Four, D. M.(2007). Singapore daisy (Wedeliatrilobata L.) manure as inorganic nitrogen fertilizer substitution in pakchoi (Brassica oleracea L.). in Proceeding of the 2nd Internasional Symposium on Food Security. Agriculture Development \& Environmental Conservation in Southeast and East Asia. Bogor. September 4-6. 2007.

Setyowati, N., Nurjannah, U. and Haryanti, D.( 2008). Gulmatusukkonde (Wedeliatrilobata) dankirinyu (Chromolaenaorodata) sebagaipupukorganikpadasawi. AktaAgrosia 2(1): 47-56. (in Indonesian Languange).

Setyowati, N., Nurjanah, U. andKorisma, R.(2009).Korelasiantarasifatsifattanahdenganhasilcabaimerahpadasubtitusipupukanorganikdenganbokasitusukkon de(WedeliatrilobataL). JurnalAktaAgrosia, 12(2).184-194.(In Indonesian Language).

Setyowati, N., Muktamar, Z., Suriyanti, B. and Simarmata, M.(2014a). Growth and yield of chili pepper as affected by weed based organic compost and nitrogen fertilizer. Int. Journal on Advanced Science Engineering Information Technologi 4(2): 84-87.

Setyowati, N., Muktamar, Z.,Oktiasa, S. and Ganefianti, D.W.(2014b). Growth and yield of chili pepper under different time application of wedelia (Wedeliatrilobata) and siam weed (Chromolaenaodorata) organic fertilizers. Int. Journal on Advanced Science Engineering Information Technologi 4(6): 13-16.

Simanungkalit, R.D.M. (2006). Prospekpupukorganikdanpupukhayati di Indonesia.BalaiBesarLitbangSumberdayaLahanPertanian.

BadanPengembangandanPenelitian.Bogor (in Indonesian Language).

Suntoro, Syekhfani, Hardayanto, E. and Soemarno.(2001). Penggunaanbahanpangkaskriyu (Cromalaenaordata) untukmeningkatkanketersediaan $\quad$ P. $\quad$ K. $\quad$ Ca. dan $\quad \mathrm{Mg}$ padaOxicDystrudepten di JumapoloKarangayarJawa Tengah.Agritivia. (in Indonesian Language).

Spark D. (2003).Environmental Soil Chemistry.2n edition.Acvademic Press. New York.

Supriyono, E., Winantuningsih, Sutopo, and Widyaningrum, A.(2005).Pemanfaatanencenggondok (Eichorniacrassipes) sebagaipupukdenganmempercepatpengomposanpadapertanamankacangtanah. in Proc. Konferensi XIII HimpunanIlmuGulma Indonesia (HIGI. pp. 313-316. Yogyakarta. Indonesia 20-21 July 2005. (in Indonesian Language).

Ullah, M.S., Islam,M.S. Islam, M.A. and Huque, T.(2008). Effects of organic manures and chemical fertilizers on the yield of brinjal and soil properties. J. Bangladesh Agril. Univ. 6(2): 271-276. 